\title{
ANALISIS PENILAIAN KINERJA (KEUANGAN DAN NON KEUANGAN) PADA SPBU X MENGGUNAKAN PENDEKATAN BALANCE SCORECARD”.
}

\author{
SUSNANINGSIH MU'AT
}

susnaningsihm@yahoo.com

\begin{abstract}
ABSTRAK
Penelitian ini bertujuan menganalisis kinerja keuangan dan non keuangan pada SPBU X. Analisis penilian kinerja ini menggunakan pendekatan Balance Scorecard yang meliputi perspektif keuangan, perspektif pelanggan, perspektif proses bisnis internal dan perspektif pertumbuhan pembelajaran. Data yang digunakan dalam penelitian ini adalah data primer dan data sekunder, baik bersifat kuantitatif maupun kualitatif. Data primer diperoleh secara langsung melalui survei kepuasan pelanggan menggunakan metode sampling insidental dan survei kepuasan karyawan menggunakan metode sensus, serta hasil dari pengamatan dilapangan dan wawancara dengan manajer SPBU X. Data sekunder diperoleh dari dokumen-dokumen tertulis dari SPBU X, internet, lembaga-lembaga yang terkait, dan studi pustaka. Kuesioner kepuasan konsumen dan karyawan dianalisis melalui uji validitas dan reliabilitas.

Penilaian kinerja pada perspektif keuangan dilakukan dengan mengkaji laporan laba rugi, neraca dan arus kas dari laporan keuangan SPBU X periode 2010, 2011, 2012. Kinerja keuangan diukur dari nilai Current Asset, Debt Ratio, Return on Asset (ROA) dan Total Asset Turn Over (TATO), menunjukan hasil yang memuaskan dengan skor akhir 93.75\%. Pada perspektif pelanggan, kinerja SPBU X dinilai cukup baik dengan skor akhir $70 \%$, yang dianalisis melalui survei kepuasan konsumen dan menghitung tingkat profitabilitas konsumen. Penilaian pada perspektif proses bisnis internal menunjukan hasil yang baik dengan skor akhir $83.3 \%$, kriteria pengukuran dianalisis melalui inovasi penjualan produk dan jasa yang dilakukan, minimalisasi masalah dan kecepatan pelayanan. Kinerja SPBU X pada perspektif pertumbuhan dan pembelajaran dinilai belum optimal dengan skor akhir 66.6\%. Kinerja keseluruhan SPBU X melalui pendekatan Balance Scorecard dinilai cukup baik dengan skor akhir $77.98 \%$. SPBU X sebaiknya memperhatikan aspek-aspek nonkeuangan lainnya dan direkmendasikan untuk menggunakan konsep Balance Scorecard sebagai sistem pengukuran kinerja dalam pencapaian visi, misi dan tujuan perusahaan.
\end{abstract}

Kata kunci: Strategi, Penilaian Kinerja, Balance Scorecard, SPBU.

\section{PENDAHULUAN}

Indonesia merupakan negara yang memiliki banyak sumber daya alam yang merupakan modal penting dalam pembangunan nasional dan peningkatan kemakmuran masyarakat. Salah satu sumber daya alam yang ada di Indonesia adalah minyak bumi dan gas bumi, yang sebagian besar pengelolaannya diberikan kepada Pertamina.

Pertamina adalah perusahaan minyak dan gas bumi yang dimiliki oleh Pemerintah Indonesia (National Oil Company). Maksud didirikannya Pertamina adalah untuk menyelenggarakan usaha di bidang minyak dan gas bumi, baik didalam maupun luar negeri serta kegiatan usaha lain yang terkait, 
juga untuk menunjang kegiatan usaha dibidang minyak dan gas bumi tersebut.

Pertamina kemudian melaksanakan pendistribusian dan pemasaran atas keseluruhan produknya terutama untuk memenuhi kebutuhan masyarakat Indonesia. Dalam kegiatan pendistribusian produk Pertamina, khususnya BBM, Pertamina dituntut untuk melaksanakan pendistribusian ke seluruh pelosok tanah air dalam jumlah yang cukup, waktu yang cepat, mutu yang baik dan harga yang layak (sesuai ketentuan berlaku).

Luasnya wilayah yang harus dijangkau oleh Pertamina dalam pendistribusian BBM mengharuskan Pertamina melakukan kerja sama dengan pihak ketiga sebagai mitra kerja yang akan menyalurkan BBM, serta produk lain yang disediakan dan dijual oleh Pertamina. Pengusaha pemilik SPBU (Stasiun Pengisian Bahan Bakar Minyak Umum) sebagai salah satu mitra kerja Pertamina dalam kegiatan penyaluran BBM dalam mengemban tugas dari Pertamina untuk melayani kebutuhan masyarakat dengan cara yang mudah, cepat, tertib dan aman.

Dari struktur kepemilikan ada 3 jenis SPBU Pertamina, yaitu:

1. SPBU DODO (Dealer Owned Dealer Operated) yaitu SPBU milik swasta, baik lahan, aset, maupun pengoperasiannya, seluruhnya adalah dimiliki dan dikelola oleh swasta.

2. SPBU CODO (Company Owned Dealer Operated) yaitu SPBU sebagai bentuk kerja sama antara Pertamina dengan swasta.

3. SPBU COCO (Company Owned Company Operated) yaitu SPBU yang dimiliki dan dikelola oleh Pertamina, dalam hal ini adalah PT Pertamina Retail (anak perusahaan dari PT Pertamina Persero).
Dalam perkembangannya, sejalan dengan transformasi yang dilaksanakan di Pertamina, SPBU dapat dibedakan menjadi dua, yaitu SPBU pertamina biasa (non-Pasti Pas!) dan SPBU Pasti Pas!. SPBU Pertamina Pasti Pas!adalah merupakan perwujudan nyata dari transformasi Pertamina, yaitu pembenahan industri ritel BBM. Melalui program Pertamina Way, yaitu program pembenahan manajemen dan pelayanan di SPBU yang terdiri dari 5 elemen: playanan staf yang terlatih, jaminan kualitas dan kuantitas, peralatan yang terawat dengan baik, format fisik yang konsisten, serta penawaran produk dan pelayanan bernilai tambah. Selanjutnya, SPBU Pertamina Way tersebut disertifikasi menjadi SPBU Pasti Pas!yang berarti SPBU tersebut telah memenuhi jaminan pelayanan terbaik sesuai standar internasional.

Sedangkan SPBU Pertamina biasa (non-Pasti Pas!) adalah SPBU yang belum mengikuti program Pertamina Way. Karakteristik kedua jenis SPBU ini tentunya berbeda, baik secara fisik yang dapat dilihat langsung seperti, bentuk bangunan, kondisi peralatan, pelayanan konsumen maupun yang tidak dapat terlihat langsung, misalnya tingkat kepercayaan konsumen, citra, kepastian kalibrasi pompa, dan lainnya.

Pertamina sendiri berusaha merangkul mitra kerjanya, yaitu para pengusaha SPBU untuk mengikuti program Pertamina Way Pasti Pas!dan sejak dimulainya program ini tahun 2006 mendapatkan tanggapan yang baik dari pihak SPBU, dimana SPBU yang menjadi peserta Pertamina Way dan lolos sertifikasi Pasti Pas!meningkat dari waktu ke waktu yaitu hingga periode per 31 September 2012 sebanyak 3664 SPBU yang telah lolos sertifikasi Pasti Pas! (www.majalahtambang.com). Pesatnya pertumbuhan SPBU Pertamina di Indonesia, disebabkan karena bisnis BBM termasuk bisnis favorit dengan tingkat keuntungan 
yang cukup tinggi sehingga menggiurkan pebisnis untuk ikut terjun dalam bidang usaha ritel $\mathrm{BBM}$ ini.

Lebih jauh kedepan, masuknya produk pesaing dalam penjualan BBM di Indonesia turut mempengaruhi omset penjualan BBM Pertamina. Salah satu bentuk persiapan menyambut dunia persaingan adalah menjadikan SPBU Pertamina biasa menjadi SPBU Pasti Pas!, hal ini tidak terlepas dari kinerja yang dilakukan dan memerlukan investasi yang cukup tinggi sehingga diharapkan adanya kenaikan penjualan yang akhirnya dapat menguntungkan kedua belah pihak.

SPBU merupakan ujung tombak krusial bagi Pertamina.Karenannya SPBU harus dibenahi serta dikelola secara terus menerus, Pihak SPBU harus dapat melihat sejauh mana kinerja yang telah dicapainya sesuai dengan syarat dan ketentuan Pertamina yang berstandar internasional.Tujuannya agar bisa bersaing secara luas dengan SPBU non Pertamina seperti Petronas dan Shell. Selama ini yang umum digunakan adalah pengukuran kinerja tradisional yang hanya menitikberatkan pada sektor keuangan saja. Pengukuran kinerja dengan sistem ini menyebabkan orientasi perusahaan hanya pada keuntungan jangka pendek dan cenderung mengabaikan kelangsungan hidup perusahaan dalam jangka panjang. Pengukuran kinerja yang menitikberatkan pada sektor keuangan saja kurang mampu mengukur kinerja harta-harta tak nampak (intangible assets) dan hartaharta intelektual (sumber daya manusia) perusahaan. Salah satu alat untuk mengukur kinerja perusahaan adalah dengan metode Balance Scorecard (BSC).

Melalui Balance Scorecard pengukuran kinerja perusahaan tidak hanya didasarkan pada aspek keuangan saja tetapi juga memasukan dan mempertimbangkan aspek-aspek nonkeuangan lain. Pengukuran kinerja perusahaan menggunakan pendekaatan Balance Scorecard, meliputi 4 (empat) perspektif, yaitu :

1. Perspektif keuangan (Financial Perspective),

2. Perspektif Kepuasan Pelanggan (Costumer Perspective),

3. Perspektif Efisiensi Proses Bisnis Internal (Internal Bussines Procces Efficiency),

4. Perspektif Pembelajaran dan Pertumbuhan (Learning and Growth Perspektive).

Berdasarkan uraian diatas, pada umumnya perusahaan mengukur kinerja hanya melihat dari perspektif keuangannya saja tanpa memasukkan dan mempertimbangkan aspek non keuangan. Aspek non keuangan yang sangat penting untuk mengetahui sampai sejauh mana kinerja yang sesungguhnya telah dicapai perusahaan. Dalam penelitian ini akan dilihat bagaimana kinerja (Keuangan dan NonKeuangan) pada SPBU X menggunakan pendekatan Balance Scorecard.

\section{Konsep Balance Scorecard}

Balance Scorecard merupakan alat manajemen kontemporer yang didesain untuk meningkatkan kemampuan perusahaan dalam melipatgandakan kinerja keuangan luarbiasa secara berkesinambungan (sustainable outstanding financial performance), (Mulyadi ; 2007;3).

Balance Scorecard teridiri dari dua kata: (1) kartu skor (scorecard) dan (2) berimbang (balanced). Pada tahap eksperimen awal, Balance Scorecard merupakan kartu skor yang dimanfaatkan untuk mencatat skor hasil kinerja eksekutif. Melalui kartu skor, skor yang hendak diwujudkan eksekutif di masa depan dibandingkan dengan hasil kinerja sesungguhnya. Hasil perbandingan ini dimanfaatkan untuk melakukan evaluasi atas 
kinerja eksekutif. Kata berimbang dimaksudkan untuk menunjukkan bahwa kinerja eksekutif diukur secara berimbang dari dua perspektif: keuangan dan non keuangan, jangka pendek dan jangka panjang, intern dan ekstern. Oleh karena eksekutif akan dinilai kinerja mereka berdasarkan kartu skor yang dirumuskan secara berimbang, eksekutif diharapkan akan memusatkan perhatian dan usaha mereka pada ukuran kinerja non keuangan dan ukuran jangka panjang.

Konsep Balance Scorecard berkembang sejalan dengan perkembangan pengimplementasian konsep tersebut. Balance Scorecard telah mengalami evolusi perkembangan: (1) Balance Scorecard sebagai perbaikan atas sistem pengukuran kinerja eksekutif, (2) Balance Scorecard sebagai kerangka perencanaan strategik, dan (3) Balance Scorecaard basis sistem terpadu pengelolaan kinerja personal.

Menurut Gasperz ( 2005 ; 2 ) pada dasarnya Balance Scorecard merupakan sistem manajemen bagi perusahaan untuk berinvestasi dalam jangka panjang untuk pelanggan (costumer), pembelajaran dan pertumbuhan karyawan, termasuk manajemen (learning and growth), proses bisnis internal (system) demi memperoleh hasil-hasil finansial yang memungkinkan perkembangan organisasi bisnis daripada mengelola bottom line untuk memacu hasilhasil jangka pendek. Gaspersz (2005 ; 3 ) mengatakan bahwa Balance Scorecard memberi manajemen organisasi suatu pengetahuan, keterampilan, dan sistem yang memungkinkan karyawan dan manajemen belajar dan berkembang terus-menerus (Perspektif pembelajaran dan pertumbuhan) dalam berinovasi untuk membangun kapabilitas strategis yang tepat serta efisiensi (Perspektif proses bisnis internal) agar mampu menyerahkan nilai spesifik ke pasar (perspektif pelanggan) dan selanjutnya akan mengarah pada nilai saham yang teru-menerus meningkat (perspektif financial).

Balance Scorecard digunakan untuk mengukur kinerja eksekutif di masa depan dengan keempat perspektif diatas. Dengan Balance Scorecard ukuran kinerja eksekutif memperluas ke kinerja non keuangan, sehingga ukuran kinerja menjadi komprehensif. Balance Scorecard telah menjadi sistem inti manajemen strategis, tidak hanya bagi eksekutif namun bagi seluruh personel perusahaan terutama dalam perusahaan yang telah memanfaatkan inisiatif teknologi informasi dalam sistem operasi bisnisnya. Dengan teknologi informasi, Balance Scorecard dikomunikasikan ke seluruh personel untuk berkoordinasi dalam mewujudkan berbagai sasaran strategis yang telah ditetapkan dapat dilakukan. Tahap perkembangan yang terkini, membawa Balance Scorecard dimanfaatkan untuk setiap tahap sistem manajemen strategis.

\section{Aspek-Aspek Pengukuran dalam Balance Scorecard}

\section{Perspektif keuangan (Financial)}

Kinerja keuangan memberikan gambaran prestasi bagi perusahaan tersebut yang dapat dianalisis dari laporan keuangan perusahaan.Pengukuran kinerja pada keuangan perusahaan di maksudkan untuk memberikan perbaikan-perbaikan pada perusahaan. Perbaikan-perbaikan ini tercermin dalam sasaran yang secara khusus berhubungan dengan keuntungan yang terukur, pertumbuhan usaha, dan nilai pemegang saham.

Menurut Kaplan dan Norton dalam Yuwono dan Ichsan ( 2004 ; 31), pengukuran kinerja keuangan mempertimbangkan adanya tahapan dari siklus kehidupan bisnis, yaitu: growth, sustain dan harvest. Tiap tahapan memiliki 
sasaran yang berbeda, sehingga penekanan pengukurannya berbeda pula.

Growth adalah tahapan awal siklus kehidupan perusahaan dimana perusahaan memiliki produk atau jasa yang secara signifikan memiliki potensi pertumbuhan terbaik. Disini, manajemen terikat dengan komitmen untuk mengembangkan suatu produk atau jasa baru, membangun dan mengembangkan suatu produk atau jasa dan fasilitas produksi, menambah kemampuan operasi, mengembangkan sistem, infrastruktur, dan jaringan distribusi yang akan mendukung hubungan global, serta membina dan mengembangkan hubungan dengan pelanggan.

Dalam tahap pertumbuhan, perusahaan biasanya beroperasi dengan arus kas yang negatif dan tingkat pengembalian modal rendah. Dengan demikian, tolak ukur kinerja yang cocok dalam tahap ini adalah, misalnya tingkat pertumbuhan pendapatan atau penjualan dalam segmen pasar yang telah ditargetkan.

Sustain adalah tahapan keduadimana perusahaan masih melakukan investasi dan reinvestasi dengan mengisyaratkan tingkat pengembalian terbaik. Sasaran pada tahap ini diarahkan pada besarnya tingkat pengembalian atas investasi yang dilakukan. Tolak ukur yang kerap digunakan pada tahap ini, misalnya ROI, ROCE, dan EVA.

Harvest adalah tahapan ketiga dimana perusahaan benar-benar menerima hasil investasi di tahap-tahap sebelumnya. Tidak ada lagi investasi besar, baik ekspansi maupun pembangunan kemampuan baru, kecuali pengeluaran untuk pemeliharaan danperbaikan fasilitas. Sasaran keuangan utama dalam tahap ini, sehingga dapat sebagai tolak ukur adalah memaksimumkan arus kas masuk dan pengurangan modal kerja.

\section{Perspektif Pelanggan}

Filosofi manajemen terkini telah menunjukan peningkatan pengakuan atas pentingnya costumer focus dan costumer satisfaction. Perspektif ini merupakan ukuran hasil, jadi apabila pelanggan tidak puas mereka akan mencari produsen lain yang sesuai dengan kebutuhan mereka. Kinerja yang buruk pada perspektif ini akan menurunkan jumlah pelanggan di masa depan meskipun saat ini kinerja keuangan terlihat baik.

Menurut Norton dan Kaplan dalam Yuwono dan Ichsan ( 2004 ; 32) perspektif pelanggan memiliki dua kelompok pengukuran, yaitu : Costumer core measurement dan Costumer value proposition.

\section{Perspektif Proses Bisnis Internal}

Analisis proses bisnis internal perusahaan dilakukan dengan menggunakan analisis value-chain. Manajemen perusahaan mengidentifikasi proses bisnis internal yang kritis yang harus diunggulkan perusahaan. Penilaian dalam persepektif ini memungkinkan manajer untuk mengetahui seberapa baik bisnis mereka berjalan dan apakah produk atau jasa mereka sesuai dengan spesifikasi pelanggan. Kaplan dan Norton dalam Yuwono ( 2004 ; 37 ) membagi proses bisnis internal kedalam tiga proses, yaitu :

a. Proses inovasi, dalam proses ini mengenali pemahaman tentang kebutuhan dari pelanggan dan menciptakan produk dan jasa yang mereka inginkan.

b. Proses operasi, merupakan proses untuk membuat dan menyampaikan produk atau jasa. Proses operasi terbagi menjadi dua aktivitas, yaitu proses pembuatan produk dan penyampaian kepada konsumennya.

c. Proses pelayanan purna jual, proses ini merupakan jasa pelayanan pada 
pelanggan setelah penjualan produk atau jasa tersebut dilakukan.

\section{Perspektif Pertumbuhan dan Pembelajaran}

Didalam perspektif ini mengukur hal-hal yang berhubungan dengan sumber daya manusia. Terdapat tiga dimensi yang harus dipertimbangkan dalam perspektif ini, yaitu:

a. Kemampuan karyawan

Pengukuran dilakukan atas tiga hal pokok yaitu pengukuran terhadap kepuasan karyawan, pengukuran terhadap perputaran karyawan dalam perusahaan, dan pengukuran terhadap produktivitas karyawan.

b. Kemampuan sistem informasi

Pengukuran perusahaan dapat dilakukan dengan mengukur persentase ketersediaan informasi yang diperlukan oleh karyawan mengenai pelanggannya, persentase ketersediaan informasi mengenai biaya produksi dan lain-lain.

c. Motivasi, pemberian wewenang, dan pembatasan wewenang karyawan

Pengukuran dapat dilakukan dengan beberapa dimensi, yaitu: pengukuran terhadap saran yang diberikan perusahaan dan diimplementasikan, (2) pengukuran atas perbaikan dan peningkatan kinerja karyawan, dan pengukuran terhadap keterbatasan individu dalam organisasi.

Untuk menentukan tujuan dan ukuran yang berkaitan dengan kemampuan karyawan ada tiga hal yang dipertimbangkan, yaitu: a. Produktivitas Karyawan, b. Persentase Pelatihan Karyawan yang Terampil, dan c. Kepuasan Karyawan
Kesenjangan dalam aspek finansial, pelanggan, dan proses internal perusahaan dapat dideteksi dengan menggunakan Balance Scorecard. Untuk melakukan perbaikan kinerja dan mengurangi kesenjangan tersebut perusahaan perlu melaksanakan program pelatihan karyawan dan perbaikan sistem secara berkelanjutan yang diselaraskan dengan prosedur (Wardhani dalam Zudia ; 2010;32).

Balance Scorecard menekankan pada upaya perusahaan investasi untuk kepentingan di masa datang, meliputi investasi manusia, sistem dan prosedur. Karyawan perlu diberikan pelatihan secara rutin untuk menambah keahlian atau kemampuan dalam rangka memenuhi perubahan tuntunan pelanggan dan lingkungan.Sistem perlu diperbaiki dengan memanfaatkan teknologi informasi.

Pada persepektif ini mengukur betapa pentingnya suatu organisasi bisnis untuk terus memperhatikan karyawannya, memantau kesejahteraan karyawannya dan meningkatkan pengetahuan karyawan. Hal ini terjadi karena dengan meningkatnya tingkat pengetahuan karyawan akan meningkatkan kemampuan karyawan untuk berpartisipasi dalam pencapaian hasil tujuan perusahaan.

\section{METODE PENELITIAN}

\section{Jenis Penelitian}

Penelitian ini merupakan penelitian pustaka (library research). Data yang digunakan dalam penelitian ini berupa bukubuku, jurnal dan sumber lain yang relevan. Setelah data penelitian ini terkumpul dilanjutkan dengan analisis data dengan metode analisis deskriptif kualitatif dan kuantitatif.

\section{Metode Pengambilan Sampel}

$\begin{array}{cccr}\text { Untuk } & \text { ukuran } & \text { sasaran } & \text { strategis } \\ \text { kepuasan } & \text { pelanggan } & \text { dilakukan } & \text { survei }\end{array}$


kepuasan pelanggan pada SPBU Fadli Elmi. Pengambilan sampel responden dilakukan dengan menggunakan metode samplingInsidentalyaitu teknik penentuan sampel berdasarkan kebetulan, yaitu siapa saja yang secara kebetulan / insidental bertemu dengan peneliti dapat digunakan sebagai sampel, bila dipandang orang yang kebetulan ditemui itu cocok sebagai sumber data, (Sugiyono ; 2011 ; 85 ). Jumlah sampel yang diambil dalam penelitian ini adalah 30, karena ukuran sampel yang layak dalam penelitian adalah 30 sampai 500 (Sugiyono dalam Nanang ; 2011 ; 81). Untuk ukuran sasaran strategis kepuasan dan motivasi karyawan dilakukan survei kepuasan dan motivasi karyawan pada SPBU X. Jumlah kuesioner yang disebar adalah sebanyak jumlah karyawan yang bekerja di SPBU X yaitu sebanyak 20 orang dengan menggunakan metode sensus. Sensus adalah cara pengumpulan data yang mengambil setiap elemen populasi atau karakteristik yang ada dalam populasi (Hasan ; 2002 ; 85).

\section{Metode Pengambilan Data}

Metode pengumpulan data yang relavan digunakan dalam perspektif keuangan, perspektif pelanggan, perspektif proses bisinis internal dan perspektif pertumbuhan dan pembelajaran untuk menunjang analisis penelitian adalah: 1) Wawancara: Dilakukan dengan nara sumber dari pihak perusahaan, yaitu manajer operasional dan FAP (Financial and Personalia) SPBU Nomor 14.283.6116 untuk memperoleh gambaran yang jelas mengenai informasi perusahaan yang dibutuhkan dalam penelitian, serta informasi mengenai penentuan target serta pembobotan sasaran strategis dan ukuran strategis untuk rancangan Balance Scorecard.2) Studi Kepustakaan: data dan informasi diperoleh dengan cara membaca, mempelajari, dan mengutip pendapat dari berbagai buku, skripsi, dan arsip-arsip laporan perusahaan. 3) Kuisioner: Untuk survei kepuasan konsumen, diberikan kepada 30 konsumen yang berkunjung ke SPBU Fadli Elmi dan untuk survei kepuasan dan motivasi karyawan, kusioner diberikan kepada seluruh karyawan SPBU Fadli Elmi.

\section{Pengolahan Data}

Kuesioner penelitian yang sudah diisi oleh responden akan diuji dengan uji validitas dan reliabilitas. Dalam Sujianto (2009; 105), uji validitas digunakan untuk mengukur sah atau valid tidaknya suatu kuesioner. Suatu kuesioner dinyatakan valid jika nilai Corrected Item-Total Correlation lebih besar dibandingkan 0.3 seperti yang dijelaskan oleh Sugiyono, Sugiyono (2011; 126) yang menyatakan bila korelasi tiap faktor positif dan besarnya 0.3 ke atas maka faktor tersebut merupakan construct yang kuat. Reliabilitas instrumen adalah hasil pengukuran yang dapat dipercaya. Reliabilitas instrumen diperlukan untuk mendapatkan data sesuai dengan tujuan pengukuran. Untuk mencapai hal tersebut, dilakukan uji reliabilitas dengan menggunakan mettode Alpha Croncbach's yang diukur berdasarkan skala Alpa Croncbach's 0 sampai 1.

Kemudian penolahan data dilakukan dengan menghitung bobot dan skor menggunakan nilai rata-rata jumlah indicator. Cara menghitung Bobot dan Skor balance Scorecard adalah memberikan bobot untuk masing-masing indikator, dengan menghitung banyaknya indikator dan menghitung bobot indikator berdasarkan nilai rata-rata bobot untuk perspekktif yang bersangkutan dibagi dengan banyaknya indikator. Misalnya perspektif keuangan diberi bobot sebanyak 26 dan jumlah indikator di perspektif keuangan ini adalah 4. Maka bobot masing-masing indikator pada perspektif keuangan ini adalah 26/4 = 6,5 . 


\section{ANALISIS DAN PEMBAHASAN}

1. Pembobotan Perspektif Balanced Score Card

Balance Scorecard merupakan sistem pengukuran kinerja komprehensif yang meliputi aspek keuangan dan aspek nonkeuangan. Langkah awal yang harus dilakukan adalah menetapkan bobot pada masing-masing perspektifuntuk mencapai tujuan utama yang ditetapkan. SPBU $X$ memberikan bobot pada perspektif keuangan dan pelanggan masing-masing sebesar $30 \%$. Pertumbuhan penjualan didukung oleh kepuasan dan kepercayaan pelanggan kepada perusahaan, yang kemudian akan mencapai pertumbuhan profitabilitas. Kedua perspektif ini sama pentingnya dalam keberhasilan perusahaan. Sedangkan untuk perspektif proses bisnis internal dan perspektif pertumbuhan dan pembelajaran, SPBU $\mathrm{X}$ memberikan bobot masing-masing sebesar $20 \%$ perusahaan membutuhkan Sumber daya yang berkualitas dan didukung dengan pengembangan produk terbaru dan promosi. Perusahaan menganggap kedua perspektif ini sama pentingnya dalam memberikan kontribusi mencapai keberhasilan perusahaan. Pencapaian tujuan strategi dapat dilakukan dengan cara menentukan ukuran sasaran yang relavan. Ukuran sasaran tersebut terdiri dari ukuran hasil (lagging indicator) yang dapat dijabarkan pada tabel 1 dibawah ini:

Tabel 1 Pembobotan Balance Scorecard

\begin{tabular}{|c|c|}
\hline Sasaran Strategi & Lagging Indicators \\
\hline $\begin{array}{l}\text { Perspektif Keuangan (F) (30\%) } \\
\text { 1. Peningkatan Likuiditas Perusahaan } \\
\text { 2. Turunya tingkat hutang perusahaan } \\
\text { 3. Peningkatan efektivitas perusahaan } \\
\text { 1. Peningkatan Profitabilitas perusahaan }\end{array}$ & $\begin{array}{l}\text { Current Assets } \\
\text { Debt to Equity Ratio } \\
\text { Total Assets Turn Over } \\
\text { ROA }\end{array}$ \\
\hline $\begin{array}{l}\text { Perspektif Konsumen }(\mathbf{C})(\mathbf{3 0} \%) \\
\text { 1. Peningkatan Kepuasan Konsumen } \\
\text { 2. Peningkatan pendapatan dari produk dan jasa yang } \\
\text { ditawarkan kepada konsumen }\end{array}$ & $\begin{array}{l}\text { Survey kepuasan konsumen } \\
\text { Rasio Profatibiltas konsumen }\end{array}$ \\
\hline $\begin{array}{l}\text { Prospektif Bisnis Internal (I) (20\%) } \\
\text { 1. Pengembangan Produk dan Jasa } \\
\text { 2. Minimalisasi Masalah } \\
\text { 3. Meningkatkan kecepatan pelayanan }\end{array}$ & $\begin{array}{l}\text { Penjualan produk baru } \\
\text { Tanggapan keluhan pelanggan } \\
\text { Waktu pemesanan produk }\end{array}$ \\
\hline Perspektif Pertumbuhan dan Pembelajaran (G) & \\
\hline
\end{tabular}




\section{(20\%)}

1. Peningkatan kepuasan karyawan

2. Peningkatan produktivitas karyawan.

3. Meningkatkan hubungan dengan karyawan

Survey kepuasan karyawan

produktvitas karyawan

Retensi Karyawan

Sumber: Wawancara FAP Manajer SPBU X (diolah)

2. Hasil Penilain Kinerja pada masingmasing Perspektif

a. Hasil Penilaian Kinerja Pada Perspektif Keuangan

Pengukuran kinerja perspektif keuangan pada SPBU $X$ dengan konsep Balance Scorecarddilakukan melalui empat tolak ukur menggunakan rasio keuangan, antara lain :

\section{CR (Current Ratio)}

Rasio likuiditas yang di gunakan dalam penelitian ini adalah menggunakan Curren Ratio untuk mengukur kemampuan perusahaan dalam memenuhi kewajiban jangka pendek dengan asumsi bahwa semua aktiva lancar dikonversikan kedalam kas. Rumusnya adalah:

Current Ratio $=\frac{\text { Aktiva lancar (CurrentAssets) }}{\text { Hutang Lancar (CurrentLiabilities) }} \times 100 \%$

Rasio ini sangat bermanfaat untuk mengetahui sampai seberapa jauh perusahaan dapat melunasi hutang jangka pendeknya. Semakin besar rasio yang diperoleh, semakin lancar hutang pembayaran jangka pendeknya (Rangkuti; 2011 ; 184). Perhitungan Current Assets pada SPBU X dapat dilihat pada tabel 2 dibawah ini:

Tabel 2 Current Assets Pada SPBU X

\begin{tabular}{|c|c|c|c|}
\hline & $\begin{array}{c}\text { Tahun 2010 } \\
(\mathbf{R p})\end{array}$ & $\begin{array}{c}\text { Tahun 2011 } \\
(\mathbf{R p})\end{array}$ & $\begin{array}{c}\text { Tahun 2012 } \\
\text { (Rp) }\end{array}$ \\
\hline Aktiva Lancar & 823.235 .653 & 1.714 .555 .065 & 2.887 .784 .723 \\
\hline Pasiva Lancar & 214.636 .425 & 286.545 .075 & 322.227 .019 \\
\hline \%CR & 3.83 atau 383\% & 5.98 atau 598\% & 8.96 atau $896 \%$ \\
\hline Rata-rata & & \multicolumn{3}{|c}{6.25 atau 625\% } \\
\hline
\end{tabular}

Sumber: SPBU X (diolah).

Dari hasil analisis, Current ratio pada SPBU X dari tahun 2010-2012 terus meningkat yaitu $383 \%$ atau 3.83 pada 2010 , $598 \%$ atau 5.98 pada 2011 dan $896 \%$ atau 8.96 pada tahun 2012. Rata-rata current ratio $625 \%$ atau 6.25. Hal ini memberikan indikasi jaminan yang baik bagi kreditor jangka pendek, dalam arti setiap saat perusahaan memiliki kemampuan untuk melunasi kewajiban-kewajiban finansial jangka pendeknya. 
Hasil wawancara dengan manajer FAP (Financial and Personalia), SPBU X menetapkan nilai target rata-rata $\mathrm{CR}$ sebesar $750 \%$ atau 7.50. Dilihat dari perhitungan rata-rata Current ratio dari tahun 2010-2012 maka, besarnya persentase pencapaian target SPBU X adalah sebesar $83.33 \%$. Selanjutnya adalah mengukur jumlah skor indikator Current Asset dengan memberikan

Interval kelas $=\frac{\text { (Nilai target }- \text { Nilai minimum) }}{4}$

$$
\text { Interval kelas } \mathrm{CR}=\frac{(750 \%-0)}{4}=187.5 \%
$$

Jadi, kriteria skor indikator CR adalah :

$$
\begin{aligned}
& A=562.5-750 \% \\
& B=375-<562.5 \% \\
& C=187.5 \%-<375 \% \\
& D=<187.5 \%
\end{aligned}
$$

Berdasarkan perhitungan rata-rata Current Asset pada SPBU Fadli Elmi yaitu sebesar $625 \%$ atau 6.25 maka, dapat ditentukan skor indikator Current Ratio adalah A karena berada pada interval $562.5 \%$ - 750\%.nilai $\mathrm{A}=4, \mathrm{~B}=3, \mathrm{C}=2$ dan $\mathrm{D}=1$, yaitu dengan menggunakan nilai interval kelas dan rumus:

\section{DR (Debt to Total Asset)}

Ukuran yang dipakai untuk mengetahui Rasio leverage dalam penelitian ini adalah dengan menggunakan Debt to Total Asset, yaitu perbandingan antara total kewajiban (total hutang) dengan total aktiva. Rasio ini menunjukan berapa bagian dari seluruh aktiva yang dibelanjai oleh hutang. Rumusnya adalah:

$$
\text { Debt to Total Asset }=\frac{\text { Total Hutang }}{\text { Total Aktiva }} \times 100 \%
$$

Perhitungan nilai Debt to Total Asset pada SPBU X dapat dilihat pada tabel 3 dibawah ini:

Tabel 3 Debt to Total Asset SPBU Fadli Elmi

\begin{tabular}{|c|c|c|c|}
\hline & $\begin{array}{c}\text { Tahun 2010 } \\
(\mathbf{R p})\end{array}$ & $\begin{array}{c}\text { Tahun 2011 } \\
(\mathbf{R p})\end{array}$ & $\begin{array}{c}\text { Tahun 2012 } \\
(\mathbf{R p})\end{array}$ \\
\hline Total Hutang & 3.867 .956 .678 & 2.772 .091 .911 & 1.540 .000 .437 \\
\hline Jumlah Aktiva & 7.335 .060 .111 & 7.487 .858 .999 & 7.922 .568 .131 \\
\hline DR\% & 0.53 atau 53\% & 0.36 atau 36\% & 0.19 atau 19\% \\
\hline Rata-Rata & \multicolumn{3}{|c}{0.36 atau 36\% } \\
\hline
\end{tabular}

Sumber: SPBU X (diolah).

Dari perhitungan Debt to Total Asset pada data keuangan SPBU X tahun 2010 2012 mengalami penurunan, yaitu 53\% pada tahun 2010, 36\% pada tahun 2011 dan 19\% pada tahun 2012 (Grafik 5.2), meskipun pada tahun 2012 nilai DR menurun menjadi $19 \%$ namun jika di rata-ratakan dari tahun
2010 sampai tahun 2012 didapat nilai Debt to Total Asset sebesar 36\%.

Hasil wawancara dengan manajer FAP (Financial and Personalia), SPBU X menetapkan nilai target rata-rata DR sebesar maksimal 50\%. Selanjutnya adalah mengukur jumlah skor indikator Debt to 
Total Asset dengan memberikan nilai $\mathrm{A}=4$, $\mathrm{B}=3, \mathrm{C}=2$ dan $\mathrm{D}=1$, yaitu dengan menggunakan nilai interval kelas dan rumus:

$$
\begin{aligned}
& \text { Interval kelas }=\frac{(\text { Nilai target }- \text { Nilai minimum })}{4} \\
& \text { Interval kelas DR }=\frac{(50 \%-0)}{4}=12.5 \%
\end{aligned}
$$

Jadi, kriteria skor indikator DR adalah :

$$
\begin{aligned}
& A=37.5 \%-50 \% \\
& B=25 \%-<37.5 \% \\
& C=12.5 \%-<25 \% \\
& D=<12.5 \%
\end{aligned}
$$

Berdasarkan perhitungan rata-rata Debt to Total Asset pada SPBU Fadli Elmi yaitu sebesar 36\% maka, Nilai DR yang diperoleh masih dibawah target yang diinginkan perusahaan. Selanjutnya, dapat ditentukan skor indikator Debt to total Asset pada SPBU Fadli Elmi adalah B karena berada pada interval $25-<37.5 \%$

\section{ROA (Return On Assets)}

ROA merupakan rasio yang digunakan untuk mengukur kemampuan manajemen dalam memperoleh laba secara keseluruhan. Rumusnya adalah:

$$
\begin{aligned}
& \text { Return on Assets }(\mathrm{ROA})=\frac{\text { Laba bersih setelah pajak }}{\text { Total Aktiva }} \times 100 \% \\
& \text { Perhitungan ROA pada SPBU X } \\
& \text { dapat dilihat pada tabel } 4 \text { dibawah } \\
& \text { ini: }
\end{aligned}
$$

Tabel 4 Return on Assets Pada SPBU X

\begin{tabular}{|c|c|c|c|}
\hline & Tahun 2010 (Rp) & Tahun 2011 (Rp) & Tahun 2012 (Rp) \\
\hline Laba bersih Stlh Pajak & 505.076 .243 & 1.514 .135 .383 & 1.534 .137 .438 \\
\hline Total Aktiva & 7.335 .060 .111 & 7.487 .858 .998 & 7.922 .568 .132 \\
\hline ROA \% & 0.07 atau 7\% & 0.20 atau 20\% & 0.19 atau 19\% \\
\hline Rata-Rata & \multicolumn{3}{|c}{0.15 atau 15\% } \\
\hline
\end{tabular}

Sumber: SPBU X (diolah).

Dari perhitungan di atas dapat dilihat bahwa ROA meningkat dari tahun ke tahun yaitu dari tahun 2010 sebesar $7 \%$ meningkat pada tahun 2011 menjadi 20\%, dan pada tahun 2012 ROA mengalami penurunan menjadi $19 \%$. Semakin besar rasio ini maka perusahaan semakin baik artinya aktiva perusahaan lebih cepat berputar dan memperoleh laba.

Hasil wawancara dengan manajer FAP (Financial and Personalia), SPBU X menetapkan nilai target rata-rata ROA sebesar $20 \%$. Dilihat dari perhitungan ratarata ROA dari tahun 2010-2012 maka, 
besarnya persentase pencapaian target SPBU $\mathrm{X}$ adalah sebesar $75 \%$. Selanjutnya adalah mengukur jumlah skor indikator ROA

$$
\begin{aligned}
& \text { Interval kelas }=\frac{(\text { Nilai target }- \text { Nilai minimum })}{4} \\
& \text { Interval kelas ROA }=\frac{(20 \%-0)}{4}=5 \%
\end{aligned}
$$

Jadi, kriteria skor indikator ROA adalah :

$$
\begin{aligned}
& A=15 \%-20 \% \\
& B=10 \%-<15 \% \\
& C=5 \%-<10 \% \\
& D=<5 \%
\end{aligned}
$$

Berdasarkan perhitungan rata-rata ROA pada SPBU Fadli Elmi yaitu sebesar $15 \%$ maka, dapat ditentukan skor indikator ROA adalah A karena berada pada interval $15 \%-20 \%$. dengan memberikan nilai $\mathrm{A}=4, \mathrm{~B}=3, \mathrm{C}=2$ dan $\mathrm{D}=1$, yaitu dengan menggunakan nilai interval kelas dan rumus:

\section{TATO (Total Assets Turn Over)}

Activity ratio ini mengukur sejauh mana efektifitas manajemen perusahaan dalam mengelola asset-asetnya. Dalam penelitian ini menggunakan pengukuran Total Asset Turnover (Perputaran Aktiva) yang mengukur perputaran dari semua asset yang dimiliki perusahaan. Total Asset Turnover dihitung dari pembagian antara penjualan dengan total asetnya. Rumusnya adalah:

$$
\text { Total Asset Turnover }(\text { TATO })=\frac{\text { penjualan Besih }}{\text { Total Aktiva }} \times 100 \%
$$

Perhitungan TATO dari tahun 2010 sampai tahun 2012 dapat dilihat pada tabel 5.5 dibawah ini:

Tabel 5 Total Assets Turn Over SPBU X

\begin{tabular}{|c|c|c|c|}
\hline & $\begin{array}{c}\text { Tahun 2010 } \\
(\mathbf{R p})\end{array}$ & $\begin{array}{c}\text { Tahun 2011 } \\
(\mathbf{R p})\end{array}$ & $\begin{array}{c}\text { Tahun 2012 } \\
(\mathbf{R p})\end{array}$ \\
\hline $\begin{array}{c}\text { Penjualan } \\
\text { Bersih }\end{array}$ & 71.545 .475 .000 & 95.515 .025 .000 & 107.409 .006 .250 \\
\hline Total Aktiva & 7.335 .060 .111 & 7.487 .858 .998 & 7.922 .568 .132 \\
\hline TATO \% & 9.75 atau 975\% & 12.76 atau 1276\% & 13.56 atau 1356\% \\
\hline Rata-Rata & \multicolumn{3}{|c}{ 12.02 atau 1202\% } \\
\hline
\end{tabular}

Sumber: SPBU X (diolah).

Dari hasil perhitungan diatas terlihat bahawa rasio aktivitas TATO yang diperoleh dari pembagian antara penjualan bersih dengan total aktiva, menunjukkan angka TATO yang meningkat dari tahun 2010 sebesar $975 \%$ menjadi $1276 \%$ pada tahun 2011 meningkat lagi pada tahun 2012 menjadi $1356 \%$. Rata-rata TATO pada SPBU X dari tahun 2010-2012 sebesar
1202\%, artinya perusahaan mampu menghasilkan penjualan yang meningkat setiap tahunnya dari setiap rupiah asetnya.

Hasil wawancara dengan manajer FAP (Financial and Personalia), SPBU X menetapkan nilai target rata-rata TATO sebesar $1500 \%$. Dilihat dari perhitungan rata-rata TATO dari tahun 2010-2012 maka, besarnya persentase pencapaian target SPBU 
Fadli Elmi adalah sebesar $80.13 \%$. Selanjutnya adalah mengukur jumlah skor indikator TATO dengan memberikan nilai A $=4, \mathrm{~B}=3, \mathrm{C}=2$ dan $\mathrm{D}=1$, yaitu dengan menggunakan nilai interval kelas dan rumus: Interval kelas $=\frac{(\text { Nilai target }- \text { Nilai minimum })}{4}$ Interval kelas TATO $=\frac{(1500 \%-0)}{4}=375 \%$ TATO adalah :

Jadi, kriteria skor indikator

$$
\begin{aligned}
& A=1125 \%-1500 \% \\
& B=750 \%-<1125 \% \\
& C=375 \%-<750 \% \\
& D=<375 \%
\end{aligned}
$$

Berdasarkan perhitungan rata-rata TATO pada SPBU X yaitu sebesar $1202 \%$ maka, dapat ditentukan skor indikator TATO adalah A karena berada pada interval $1125 \%-1500 \%$.

b. Hasil Penilaian Kinerja pada Perspektif Pelanggan.

Penilaian kinerja pada perspektif pelanggan dilihat dari persentase kepuasan konsumen dapat di ukur dengan menggunakan Survey kepuasan konsumen, dan persentase profitabilitas konsumen. Dalam penelitian ini alat ukur yang digunakan adalah :

\section{Survey Kepuasan Konsumen}

Hasil uji reliabilitas dan validitas kuesioner untuk mengukur kepuasan konsumen menunjukkan hasil yang valid dan reliable. Tanggapan konsumen mengenai penawaran produk, prosedur pelayanan, penanganan keluhan pelanggan, kondisi dan kualitas karyawan, fasilitas dan peralatan perusahaan dan kenyamanan SPBU dinyatakan reliable, dengan indikator untuk uji reliabilitas adalah Cronbach's
Alpha. Apabila Cronbach's Alpha> 0.6 menunjukan instrument yang digunakan reliable.

Uji validitas digunakan untuk mengukur sah atau tidaknya suatu kuesioner. Suatu item dikatakan valid jika nilai Corrected Item-Total Correlation lebih besar dibandingkan 0.3 .

Dari hasil uji validitas diketahui bahwa keseluruhan variabel penelitian ini memiliki nilai Corrected Item-Total Correlation diatas tingkat signifikasi 0.3 sehingga data kuesioner kepuasan konsumen dikatakan valid. Untuk mengetahui tingkat kepuasan konsumen terhadap atribut pada SPBU X dapat dilihat skor rata-rata (mean) kepuasan konsumen sebesar 4.17. Angka yang dihasilkan dari nilai rata-rata ini menginterprestasikan bahwa angka diatas 4.00 memiliki penilaian dengan kategori puas/baik.

Hasil wawancara dengan manajer operasional, SPBU X menetapkan nilai target rata-rata kepuasan konsumen sebesar 5.00. Dilihat dari perhitungan rata-rata kepuasan konsumen, besarnya persentase pencapaian target SPBU Fadli Elmi adalah $83.4 \%$. Selanjutnya adalah mengukur jumlah skor indikator kepuasan konsumen dengan memberikan nilai $\mathrm{A}=4, \mathrm{~B}=3, \mathrm{C}=2, \mathrm{D}=1$ dan $\mathrm{E}=0$, yaitu dengan menggunakan nilai interval kelas dan rumus:

$$
\begin{aligned}
& \text { Interval kelas }=\frac{(\text { Nilai target }- \text { Nilai minimum })}{5} \\
& \text { Interval kelas kepuasan konsumen }=\frac{(5.00-1)}{5}=0.8 \\
& \text { Jadi, kriteria skor indikator }
\end{aligned}
$$
kepuasan konsumen adalah :

$$
\begin{aligned}
& A=4.3-5.0 \\
& B=3.5-4.2 \\
& C=2.7-3.4 \\
& D=1.9-2.6
\end{aligned}
$$




$$
\mathrm{E}=1.0-1.8
$$

Berdasarkan perhitungan rata-rata kepuasan konsumen pada SPBU X yaitu sebesar 4.17 maka, dapat ditentukan skor indikator kepuasan konsumen adalah B karena berada pada interval 3.5 - 4.2. Terkait penilaian tersebut, SPBU X akan berusaha memberikan pelayanan terbaik. Hal ini bertujuan untuk mempertahankan loyalitas kepada konsumen serta meningkatkan pencapaian konsumen baru.

\section{Profitabilitas Konsumen}

Profitabilitas Konsumen digunakan untuk mengukur seberapa besar keuntungan yang berhasil dicapai perusahaan dari penjualan produk Pertamina yang ditawarkan kepada konsumen dengan cara membagi laba bersih sebelum pajak dengan penjualan bersih. Profitabilitas konsumen dapat dilihat pada tabel 5.9 dibawah ini:

\section{Tabel 6 Profitabilitas Konsumen SPBU X}

\begin{tabular}{|c|c|c|c|}
\hline & Tahun 2010 (Rp) & Tahun 2011(Rp) & Tahun 2012 (Rp) \\
\hline Laba Bersih Sebelum Pajak & 719.712 .669 & 1.800 .680 .458 & 1.856 .364 .457 \\
\hline Penjualan Bersih & 71.545 .475 .000 & 95.515 .025 .000 & 107.409 .006 .250 \\
\hline \% Profitabiltas konsumen & $1.01 \%$ & $1.88 \%$ & $1.72 \%$ \\
\hline Rata-Rata & \multicolumn{3}{|c|}{$1.53 \%$} \\
\hline
\end{tabular}

Sumber: SPBU Fadli Elmi Nomor 14.283.6116 (diolah)

Hasil tabel 6 menjelaskan bahwa persentase profitabilitas konsumen pada tahun 2010 sebesar $1.01 \%$ serta tahun 2011 meningkat menjadi $1.88 \%$ dan mengalami penurunan menjadi $1.72 \%$ pada tahun 2012 . Meskipun nilai rata-rata lebih tinggi dibandingkan profitabilitas konsumen pada tahun 2010 namun profitabilitas perusahaan semakin meningkat pada tahun-tahun berikutnya melebihi nilai rata-rata, jadi semakin tinggi nilai profitabilitas konsumen berarti menunjukan semakin tinggi laba yang berhasil dicapai oleh perusahaan.

Hasil wawancara dengan manajer FAP (financial and Personalia), SPBU Fadli Elmi menetapkan nilai target rata-rata profitabilitas konsumen sebesar 2\%. Dilihat dari perhitungan rata-rata profitabilitas konsumen dari tahun 2010-2012 maka, besarnya persentase pencapaian target SPBU Fadli Elmi adalah sebesar $76.5 \%$.
Selanjutnya adalah mengukur jumlah skor indikator profitabilitas konsumen dengan memberikan nilai $\mathrm{A}=4, \mathrm{~B}=3, \mathrm{C}=2$ dan $\mathrm{D}$ $=1$, yaitu dengan menggunakan nilai interval kelas dan rumus:

Interval kelas $=\frac{(\text { Nilai target }- \text { Nilai minimum })}{4}$

Interval kelas profitabilitas konsumen $=\frac{(2 \%-0)}{4}=0.5 \%$

Jadi, kriteria skor indikator profitabilitas konsumen adalah :

$$
\begin{aligned}
& A=1.5 \%-3 \% \\
& B=1 \%-<1.5 \% \\
& C=0.5 \%-<1 \% \\
& D=<0.5 \%
\end{aligned}
$$

Berdasarkan perhitungan rata-rata profitabilitas konsumen pada SPBU X yaitu sebesar $1.53 \%$ maka, dapat ditentukan skor 
indikator profitabilitas konsumen adalah $\mathrm{A}$ karena berada pada interval $1.5 \%-3 \%$.

\section{c. Hasil Penilaian Kinerja pada \\ Perspektif Proses Bisnis Internal}

Untuk mengukur pencapaian kinerja SPBU $X$ pada perspektif proses bisnis internal dapat dari pengembangan penjualan produk / jasa baru baik itu produk Pertamina maupun non Pertamina, minimalisasi masalah keluhan pelanggan dan kecepatan dan ketepatan pelayanan.

\section{Pengembangan Penjualan Produk / Jasa Baru}

Untuk menarik pelanggan SPBU Fadli Elmi melakukan inovasi dengan pengembangan produk-produk Pertamina maupun non Pertamina, pengembangan produk baru saat ini adalah adanya penjualan produk Pertamina non BBM seperti pelumas kendaraan, dan minimarket dengan persentase keduanya sebesar $2 \%$, lebih jauh kedepan untuk lebih meningkatkan pelayanan kepada konsumen SPBU Fadli Elmi akan menambah bahan bakar minyak jenis Pertamax dan Café untuk produk non BBM sehingga ditargetkan inovasi produk meingkat menjadi $4 \%$.

Selanjutnya adalah mengukur jumlah skor indikator inovasi penjualan produk / jasa baru dengan memberikan nilai $\mathrm{A}=4, \mathrm{~B}$ $=3, \mathrm{C}=2$ dan $\mathrm{D}=1$, yaitu dengan menggunakan nilai interval kelas dan rumus: Interval kelas $=\frac{(\text { Nilai target }- \text { Nilai minimum) }}{4}$
Interval kelas inovasi produk $=\frac{(4 \%-1)}{4}=0.75 \%$

Jadi, kriteria skor indikator inovasi produk / jasa baru adalah :

$$
\begin{aligned}
& A=2.25 \%-3 \% \\
& B=1.5 \%-<2.25 \% \\
& C=0.75 \%-<1.5 \%
\end{aligned}
$$

$\mathrm{D}=<0.75 \%$

Berdasarkan persentase produk yang dijual SPBU Fadli Elmi saat ini maka, dapat ditentukan skor indikator pengembangan penjualan produk / jasa baru adalah B karena berada pada interval $1.5 \%-<2.25 \%$.

\section{Minimalisasi Masalah}

Dalam hal menjaga loyalitas konsumen, SPBU menyediakan formulir keluhan pelanggan yang akan ditindaklanjuti oleh perusahaan dalam waktu 48 jam, target perusahaan adalah tidak adanya keluhan dari pelanggan, hal ini berhasil dicapai SPBU X karna tidak adanya keluhan dari pelanggan maka dalam hal ini SPBU $X$ terus mempertahankan pelayanan dengan konsumennya.

\section{Peningkatan Kecepatan pelayanan}

Dalam meningkatkan kualitas dan kuantitas bahan bakar minyak perusahaan terus mengikatkan jalinan kerja sama yang baik terhadap para pemasok dari Pertamina. Hal ini dilakukan setelah perusahaan melakukan pemesanan minyak ke PT.Pertamina, dari wawancara dengan manajer oprasional idealnya perusahaan harus memesan minyak setiap hari dengan nilai persentase $100 \%$ meliputi pemesanan premium dan solar agar ketersediaan minyak di stasiun pengisian bahan bakar selalu ada sehingga minyak tidak pernah habis, hal ini memberikan kepuasan tersendiri bagi pelanggan dan dapat meningkatkan profitabilitas perusahaan. Namun saat ini SPBU X hanya dapat memesan minyak pada Pertamina setiap 2 hari skali atau $50 \%$ dari yang seharusnya.

Selanjutnya adalah mengukur jumlah skor indikator kecepatan dan ketepatan pelayanan dengan memberikan nilai $\mathrm{A}=4$, $\mathrm{B}=3, \mathrm{C}=2$ dan $\mathrm{D}=1$, yaitu dengan menggunakan nilai interval kelas dan rumus:

$$
\text { Interval kelas }=\frac{(\text { Nilai target }- \text { Nilai minimum) }}{4}
$$




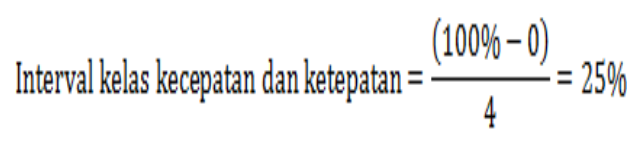

Jadi, kriteria skor indikator kecepatan dan ketepatan adalah :

$$
\begin{aligned}
& A=75 \%-100 \% \\
& B=50 \%-<75 \% \\
& C=25 \%-<50 \% \\
& D=<25 \%
\end{aligned}
$$

Berdasarkan kriteria skor indikator maka, dapat ditentukan skor indikator kecepatan dan ketepatan pelayanan adalah B karena berada pada interval 50\% - < 75\%.

\section{d. Hasil penilaian Kinerja pada perspektif Pertumbuhan dan Pembelajaran}

Tujuan strategis perspektif pertumbuhan dan pembelajaran ditentukan melalui alat pengukuran sebagai berikut :

\section{Survey Kepuasan Karyawan}

Pengujian kualitas data menggunakan uji reliabilitas dan uji validitas. Uji reliabilitas pada keseluruhan variabel tersebut menghasilkan nilai Cronbach's Alphalebih dari 0.60. sehingga hasil keseluruhan variabel mengenai kuesioner kepuasan karyawan terhadap SPBU X dikatakan reliable. Hasil Uji validitas mengenai data kuesioner kepuasan karyawan pada SPBU X menunjukkkan hasil skor nilai rata-rata keseluruhan adalah 4.16. Hasil tersebut menunjukkan hasil dengan kategori baik karena memiliki nilai rata-rata diatas 4.00. Hasil wawancara dengan manajer FAP (Financial and Personalia), SPBU Fadli Elmi menetapkan target rata-rata kepuasan konsumen adalah 5.00. Selanjutnya adalah mengukur jumlah skor indikator kepuasan karyawan dengan memberikan nilai $\mathrm{A}=4, \mathrm{~B}=3, \mathrm{C}=2, \mathrm{D}=1$ dan $\mathrm{E}=0$, yaitu dengan menggunakan nilai interval kelas dan rumus:

$$
\text { Interval kelas }=\frac{(\text { Nilai target }- \text { Nilai minimum })}{5}
$$

Interval kelas kepuasan karyawan $=\frac{(5-1)}{5}=0.8$

Jadi, kriteria skor indikator kepuasan karyawan adalah :

$$
\begin{aligned}
& \mathrm{A}=4.3-5.0 \\
& \mathrm{~B}=3.5-4.2 \\
& \mathrm{C}=2.7-3.4 \\
& \mathrm{D}=1.9-2.6 \\
& \mathrm{E}=1.0-1.8
\end{aligned}
$$

Berdasarkan perhitungan rata-rata kepuasan karyawan pada SPBU $X$ yaitu sebesar 4.16 maka, dapat ditentukan skor indikator kepuasan karyawan adalah B karena berada pada interval $3.5-4.2$.

Terkait penilaian tersebut, keberhasilan SPBU Fadli Elmi terjuwud dengan penerapan teori Gilmerdengan baik yang meliputi pemberian kompensasi, pekerjaan yang dijalani karyawan, kondisi kerja, promosi pekerjaan, hubungan dengan atasan atau kepemimpinan, hubungan dengan teman kerja dan pemberian motivasi sebagai dorongan karyawan dalam melaksanakan pekerjaannya.

\section{Produktivitas Karyawan}

Tingkat produktivitas karyawan digunakan untuk mengetahui produktivitas karyawan dalam periode tertentu pada SPBU $X$ yang dihitung dengan membagi laba usaha dengan jumlah karyawan dikali $100 \%$. Produktivitas karyawan pada tahun 2010 adalah $248.17 \%$ artinya setiap karyawan memberikan bagian laba bersih kepada perusahaan sebesar $248.17 \%$, Sedangkan pada tahun 2011 mengalami kenaikan sebesar $750.28 \%$. dan pada tahun 2012 meningkat sebesar 928.18\%. Jumlah produktivitas karyawan pada tahun 2012 
lebih besar dari jumlah rata-rata produktivitas selama tiga tahun yaitu sebesar $642.21 \%$.

Hasil wawancara dengan manajer FAP (Financial and personalia), SPBU X menetapkan nilai target rata-rata produktivitas karyawan sebesar $995 \%$. Dilihat dari perhitungan rata-rata produktivitas karyawan dari tahun 20102012 maka, besarnya persentase pencapaian target SPBU Fadli Elmi adalah 64.5\%. Selanjutnya adalah mengukur jumlah skor indikator produktivitas karyawan dengan memberikan nilai $\mathrm{A}=4, \mathrm{~B}=3, \mathrm{C}=2$, dan $\mathrm{D}$ $=1$, yaitu dengan menggunakan nilai interval kelas dan rumus:

Interval kelas $=\frac{(\text { Nilai target }- \text { Nilai minimum })}{4}$ Interval kelas produktivitas karyawan $=\frac{(995 \%-0)}{4}=248.75 \%$

Jadi, kriteria skor indikator produktivitas karyawan adalah :

$$
\begin{aligned}
& A=746.25 \%-995 \% \\
& B=497.5 \%-<746.25 \% \\
& C=248.75 \%-<497.5 \%
\end{aligned}
$$

$$
\mathrm{D}=<248.75 \%
$$

Berdasarkan perhitungan rata-rata produktivitas karyawan pada SPBU Fadli Elmi yaitu sebesar $642.21 \%$ maka, dapat ditentukan skor indikator produktivitas karyawan adalah B karena berada pada interval $497.5 \%$ - $\quad<746.25 \%$.Meskipun jumlah nilai rata-rata produktivitas karyawan masih jauh dari target yang ditetapkan, namun tingkat produktivitas karyawan telah mengalami peningkatan setiap tahun.

\section{Retensi Karyawan}

Retensi Karyawan, mengukur tingkat dimana perusahaan dapat mempertahankan hubungan dengan karyawannya. Rumusnya adalah:

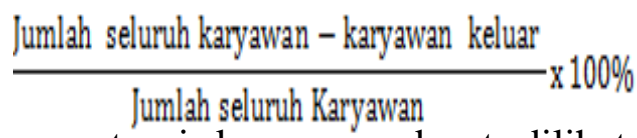
Persentase retensi karyawan dapat dilihat pada tabel 7 dibawah ini:

Tabel 7 Retensi Karyawan SPBU X

\begin{tabular}{|c|c|c|c|}
\hline Tahun & $\begin{array}{c}\text { Karyawan } \\
\text { keluar } \\
\text { (a) }\end{array}$ & $\begin{array}{c}\text { Jumlah } \\
\text { seluruh } \\
\text { karyawan } \\
\text { (b) }\end{array}$ & $\begin{array}{c}\text { Retensi } \\
\text { Karyawan } \\
\text { (b-a) } / \text { b x 100\% }\end{array}$ \\
\hline 2010 & $\mathbf{5}$ & $\mathbf{2 9}$ & $\mathbf{8 2 . 7 6}$ \\
\hline 2011 & 2 & 24 & 91.67 \\
\hline 2012 & 2 & 22 & $\mathbf{9 0 . 9}$ \\
\hline Rata-Rata & & & $\mathbf{8 8 . 4 4 \%}$ \\
\hline
\end{tabular}

Sumber: SPBU X (diolah).

Dari tabel diatas hasil dari perhitungan efektivitas kinerja perspektif pertumbuhan dan pembelajaran menunjukan hasil yang baik. Selama 3 tahun total karyawan yang keluar adalah 9 orang. Retensi karyawan meningkat dari tahun 2010 - 2011 dan kembali menurun pada tahun 2012 menjadi $90.9 \%$, namun persentase penurunan masih di atas retensi karyawan pada tahun 2010 yaitu sebesar $82.76 \%$. Dapat disimpulkan 
bahwa perspektif pertumbuhan dan pembelajaran pada SPBU $X$ masih dinilai baik.

Hasil wawancara dengan manajer FAP (Financial and personalia), SPBU X menetapkan nilai target rata-rata retensi karyawan sebesar 100\%. Dilihat dari perhitungan rata-rata retensi karyawan dari tahun 2010-2012 maka, besarnya persentase pencapaian target SPBU Fadli Elmi adalah $88.44 \%$. Selanjutnya adalah mengukur jumlah skor indikator produktivitas karyawan dengan memberikan nilai $\mathrm{A}=4$, $\mathrm{B}=3, \mathrm{C}=2$, dan $\mathrm{D}=1$, yaitu dengan menggunakan nilai interval kelas dan rumus: Interval kelas $=\frac{(\text { Nilai target }- \text { Nillai minimum })}{4}$ Interval kelas retensi karyawan $=\frac{(100 \%-0)}{4}=25 \%$ Jadi kriteria skor indikator retensi karyawan adalah : $\mathrm{A}=75 \%-100 \%$

$$
\begin{aligned}
& B=50 \%-<75 \% \\
& C=25 \%-<50 \% \\
& D=<25 \%
\end{aligned}
$$

Berdasarkan perhitungan rata-rata retensi karyawan pada SPBU Fadli Elmi yaitu sebesar $88.44 \%$ maka, dapat ditentukan skor indikator produktivitas karyawan adalah A karena berada pada interval $75 \%-100 \%$.

\section{Hasil Penilaian Kinerja Keseluruhan Pada SPBU Fadli Elmi \\ Setelah dilakukan pengukuran masing-masing perspektif kemudian} dilanjutkan dengan analisis pengukuran kinerja secara keseluruhan. Penilaian kinerja dilakukan dengan pembobotan sesuai dengan yang tetapkan SPBU X dengan hasil akhir berupa bobot indikator yang diperoleh dari membagi bobot dengan jumlah indikator yang dapat dilihat pada tabel 8 dibawah ini:

Tabel 8 Mengukur Bobot dan Bobot Indikator

\begin{tabular}{|l|l|l|c|c|c|}
\hline & \multicolumn{1}{|c|}{ Perspektif } & $\begin{array}{c}\text { Key } \\
\text { Performance } \\
\text { Indicator }\end{array}$ & $\begin{array}{c}\text { Jumlah } \\
\text { Indikator }\end{array}$ & $\begin{array}{c}\text { Bobot } \\
(\mathbf{\%})\end{array}$ & $\begin{array}{c}\text { Bobot } \\
\text { Indikator }\end{array}$ \\
\hline 1 & $\begin{array}{l}\text { Finansial } \\
4 \text { Butir }\end{array}$ & Current Asset & & 30 & 7.5 \\
\cline { 3 - 6 } & DR & & & \\
\cline { 3 - 6 } & ROA & & & \\
\cline { 3 - 6 } & TATO & & & \\
\hline
\end{tabular}




\begin{tabular}{|c|c|c|c|c|c|}
\hline \multirow[t]{3}{*}{2} & \multirow{3}{*}{$\begin{array}{l}\text { Pelanggan } \\
2 \text { Butir }\end{array}$} & & 2 & 30 & 15 \\
\hline & & $\begin{array}{l}\text { Indeks } \\
\text { kepuasan } \\
\text { konsumen }\end{array}$ & & & \\
\hline & & $\begin{array}{l}\text { Profitabilitas } \\
\text { konsumen }\end{array}$ & & & \\
\hline \multirow[t]{4}{*}{3} & \multirow{4}{*}{$\begin{array}{l}\text { Proses Internal } \\
2 . \quad \text { Butir }\end{array}$} & & 3 & 20 & 6.6 \\
\hline & & Inovasi & & & \\
\hline & & $\begin{array}{l}\text { Minimalisasi } \\
\text { masalah }\end{array}$ & & & \\
\hline & & $\begin{array}{l}\text { Kecepatan } \\
\text { pelayanan }\end{array}$ & & & \\
\hline \multirow[t]{5}{*}{4} & \multirow{4}{*}{$\begin{array}{l}\text { Pembelajaran } \\
3 \text { butir }\end{array}$} & & 3 & 20 & 6.6 \\
\hline & & $\begin{array}{l}\text { Indeks } \\
\text { kepuasan } \\
\text { karyawan }\end{array}$ & & & \\
\hline & & $\begin{array}{l}\text { Produktivitas } \\
\text { karyawan }\end{array}$ & & & \\
\hline & & $\begin{array}{l}\text { Retensi } \\
\text { karyawan }\end{array}$ & & & \\
\hline & TOTAL & & & & \\
\hline
\end{tabular}

Sumber: Diadaptasi dari Rangkuti, 2011 hlm. 143

Pada tabel 9 diatas didapat bobot indikator masing-masing yaitu pada perspektif keuangan sebesar 7.5, perspektif pelanggan 15, perspektif proses internal dan pertumbuhan pembelajaran masing-masing sebesar 6.6. Tahap selanjutnya adalah mengukur skor tertimbang maksimum yang dapat dilihat pada tabel 9 dibawah ini:

Tabel 9 Mengukur Skor Tertimbang Maksimum

\begin{tabular}{|l|c|c|c|c|}
\hline Perspektif & $\begin{array}{c}\text { Jumlah } \\
\text { Indikator }\end{array}$ & $\begin{array}{c}\text { Skor Indikator } \\
\text { Maks }\end{array}$ & $\begin{array}{c}\text { Bobot } \\
\text { Indikator }\end{array}$ & $\begin{array}{c}\text { Skor } \\
\text { Tertimbang } \\
\text { Maks }\end{array}$ \\
\hline Finansial & 4 & 4 & 7.5 & 120 \\
\hline Pelanggan & 2 & 5 & 15 & 150 \\
\hline $\begin{array}{l}\text { Proses } \\
\text { Internal }\end{array}$ & 3 & 4 & 6.6 & 79.2 \\
\hline Pembelajaran & 3 & 5 & 6.6 & 99 \\
\hline TOTAL & & & & $\mathbf{4 4 8 . 2}$ \\
\hline
\end{tabular}

Sumber: Diadaptasi dari Rangkuti, 2011 hlm.144. 
Untuk menghitung skor tertimbang maksimum, rumusnya adalah:

\section{(Jumlah Indikator x Skor Indikator x BobotIndikator)}

Tahap selanjutnya adalah menghitung jumlah skor indikator, pemberian nilai $\mathrm{A}=4, \mathrm{~B}=3, \mathrm{C}=2, \mathrm{D}=1$ untuk masing-mmasing indikator adalah berdasarkan empat kriteria masing-masing indikator (tabel 10), dengan menggunakan nilai interval kelas dan rumus:

Interval kelas $=\frac{(\text { Nilai target }- \text { Nilai minimum })}{4}$

Tabel 10 Nilai Skor Indikator

\begin{tabular}{|l|l|l|c|c|}
\hline & Perspektif & \multicolumn{1}{|c|}{$\begin{array}{c}\text { Key Performance } \\
\text { Indicator }\end{array}$} & Nilai & Skor Indikator \\
\hline \multirow{2}{*}{1} & \multirow{2}{*}{ Finansial } & Current Asset & $\mathrm{A}$ & 4 \\
\cline { 3 - 5 } & & DR & $\mathrm{B}$ & 3 \\
\cline { 3 - 5 } & & ROA & $\mathrm{A}$ & 4 \\
\cline { 3 - 5 } & & \multicolumn{2}{|c|}{ TATOTAL } & $\mathbf{1 5}$ \\
\cline { 3 - 5 } & & $\begin{array}{l}\text { Indeks kepuasan } \\
\text { konsumen }\end{array}$ & B & 3 \\
\hline 2 & Pelanggan & & \\
\hline
\end{tabular}




\begin{tabular}{|c|c|c|c|c|}
\hline & & $\begin{array}{l}\text { Profitabilitas } \\
\text { konsumen }\end{array}$ & A & 4 \\
\hline & & \multicolumn{2}{|l|}{ TOTAL } & 7 \\
\hline \multirow[t]{4}{*}{3} & \multirow[t]{4}{*}{ Proses Internal } & Inovasi & $\mathrm{B}$ & 3 \\
\hline & & Minimalisasi masalah & A & 4 \\
\hline & & Kecepatan pelayanan & $\mathrm{B}$ & 3 \\
\hline & & \multicolumn{2}{|l|}{ TOTAL } & 10 \\
\hline \multirow[t]{5}{*}{4} & \multirow[t]{4}{*}{ Pembelajaran } & $\begin{array}{ll}\text { Indeks } & \text { kepuasan } \\
\text { karyawan } & \end{array}$ & B & 3 \\
\hline & & $\begin{array}{l}\text { Produktivitas } \\
\text { karyawan }\end{array}$ & B & 3 \\
\hline & & Retensi karyawan & A & 4 \\
\hline & & \multicolumn{2}{|l|}{ TOTAL } & 10 \\
\hline & TOTAL & & & \\
\hline
\end{tabular}

Sumber: Diadaptasi dari Rangkuti, 2011 hlm. 145.

Dilihat dari tabel 10 diatas total skor indikator pada perspektif keuangan diperoleh sebesar 10 yang dihitung dari penjumlahan tiap-tiap indikator pada perspektif keuangan, total skor indikator pelanggan sebesar 7, proses internal sebesar
10 dan pertumbuhan pembelajaran memperoleh skor indikator 10. Tahap selanjutnya adalah menghitung nilai akhir total per komponen yang dapat dilihat pada tabel 11 dibawah ini:

Tabel 11 Menghitung Nilai Akhir Total per Komponen

\begin{tabular}{|l|c|c|c|}
\hline \multicolumn{1}{|c|}{ Perspektif } & $\begin{array}{c}\text { Skor Tertimbang } \\
\text { Maksimum }\end{array}$ & $\begin{array}{c}\text { Skor } \\
\text { Tertimbang }\end{array}$ & $\begin{array}{c}\text { Nilai Akhir } \\
\text { Komponen }\end{array}$ \\
\hline Keuangan & 120 & 112.5 & $93.75 \%$ \\
\hline Pelanggan & 150 & 105 & $70 \%$ \\
\hline Proses Internal & 79.2 & 66 & $83.33 \%$ \\
\hline Pembelajaran & 99 & 66 & $66.66 \%$ \\
\hline
\end{tabular}

Sumber: Diadaptasi dari Rangkuti, 2011 hlm. 146.

Rumus nilai akhir komponen (0-100) adalah:

\section{Skor Tertimbang Skor tertimbang Maksimum}

Dari tabel 11 diperoleh nilai akhir komponen pada perspektif keuangan sebesar
$93.75 \%$, pelanggan sebesar $70 \%$, proses internal sebesar $83.33 \%$ dan pembelajaran sebesar $66.66 \%$. Tahap selanjutnya adalah menghitung nilai akhir total atau total skor yang dapat dilihat pada tabel 12 dibawah ini: 
Tabel 12 Total Skor Keseluruhan

\begin{tabular}{|l|c|c|c|}
\hline \multicolumn{1}{|c|}{ Perspektif } & $\begin{array}{c}\text { Jumlah Skor } \\
\text { Indikator }\end{array}$ & $\begin{array}{c}\text { Bobot } \\
\text { Indikator }\end{array}$ & Skor Tertimbang \\
\hline Finansial & 15 & 7.5 & 112.5 \\
\hline Pelanggan & 7 & 15 & 105 \\
\hline Proses Internal & 10 & 6.6 & 66 \\
\hline Pembelajaran & 10 & 6.6 & 66 \\
\hline $\begin{array}{c}\text { Jumlah Skor } \\
\text { Tertimbang }\end{array}$ & & & $\mathbf{3 4 9 . 5}$ \\
\hline
\end{tabular}

Sumber: Diadaptasi dari Rangkuti, 2011 hlm. 146.

$=\frac{349.5}{448.2} \times 100 \%=77.98 \%$

Rumus (Total Score $)=\frac{\text { Jumlah Skor tertimbang }}{\text { Jumlah Skor' Tertimbang Maksimum }} \times 100 \%$

Selanjutnya dengan menggunakan kriteria standar kinerja perusahaan yang dapat dilihat pada tabel 13 dibawah ini:

Tabel 13 Standar Kriteria Pengukuran Perusahaan

\begin{tabular}{|l|c|l|}
\hline Kondisi & Kategori & Total Skor \\
\hline SANGAT SEHAT & AAA & $\geq 95$ \\
\hline & AA & $80<T S<95$ \\
\hline KURANG SEHAT & A & $65<T S<80$ \\
\hline & BBB & $50<T S<65$ \\
\hline & BB & $40<T S<50$ \\
\hline TIDAK SEHAT & B & $30<T S<40$ \\
\hline & CCC & $20<T S<30$ \\
\hline & CC & $10<T S<20$ \\
\hline
\end{tabular}

Sumber: Rangkuti, 2011 hlm. 147.

Kesimpulan yang diperoleh adalah, kinerja SPBU X secara keseluruhan dinilai sangat sehat dengan kategori A, dengan total

maupun non keuangan perusahaan untuk mencapai sasaran strategis yang telah ditetapkan sebelumnya.

\section{KESIMPULAN DAN SARAN}

Balance Scorecard memiliki empat perspektif, yaitu perspektif keuangan, perspektif pelanggan, perspektif proses bisnis internal, dan perspektif pertumbuhan skor sebesar $77.98 \%$. Terkait penilaian tersebut, SPBU Fadli Elmi dituntut untuk terus meningkatkan kinerja keuangan dan pembelajaran. Setiap perspektif Balance Scorecard terdiri dari sasaran strategis dan ukuran strategis. Pengukuran kinerja SPBU Fadli Elmi denngan menggunakan Balance Scorecard menjadi acuan sebagai alat evaluasi kinerja yang selama ini digunakan, sehingga pada akhirnya akan memberikan dampak positif terhadap profitabilitas dan perkembangan perusahaan. 
Hasil kinerja SPBU Fadli Elmi dalam empat perspektif Balance Scorecard dapat dilihat pada skor akhir masing-masing perspektif berikut ini:

1. Pada perspektif keuangan inerja yang dicapai SPBU Fadli Elmi sangat memuaskan dengan skor akhir sebesar 93.75\% namun, perusahaan perlu memperhatikan rasio likuiditas yang sangat tinggi. Hal ini mengidentifikasikan

3. pada SPBU Fadli Elmi dan rata-rata profitabilitas konsumen yang terus

4. meningkat dari tahun 2010 sampai dengan tahun 2012.

5. Pada perspektif proses bisnis internal kinerja perusahaan dinilai baik dengan skor akhir sebesar 83.3\%. Hal ini berkaitan dengan keberhasilan SPBU Fadli Elmi dalam memberikan pelyanan kepaada konsumennya dalam hal innovasi, minimalisasi keluhan pelanggan dan kecepatan pelayanan.

6. Pada perspektif pertumbuhan dan pembelajaran hasil kinerja SPBU Fadli Elmi dinilai belum optimal yaitu sebesar $66.6 \%$, hal ini dikarenakan rata-rata tingkat produktivitas karyawan yang masih jauh dibawah target yang telah ditetapkan.

Kinerja SPBU Fadli Elmi dalam
priode 2010 sampai dengan 2012
menunjukan kinerja yang baik, tetapi pada
masa yang akan datang dengan tingkat
persaingan yang semakin tinggi, perusahaan
memerlukan tolak ukur kinerja yang dapat
menunjukan pencapaian kinerja perusahaan
atas tujuan-tujuan strategisnya.

Oleh karena itu, perusahaan sebaiknya menggunakan Balance Scorecard sebagai sistem pengukuran kinerja perusahaan. Balance Scorecard selain tetap mempertahankan ukuran keuangan sebagai banyaknya dana yang menganggur. Keberhasilan SPBU Fadli Elmi pada perspektif keuangan dikarenakan usaha dalam meminimalisasi biaya-biaya operasional telah berhasil dicapai perusahaan

2. Pada perspektif pelanggan kinerja yang dicapai dinilai cukup baik dengan skor akhir sebesar 70\%. Penilaian tersebut dilihat dari rata-rata kepuasan konsumen

suatu ringkasan penting kinerja perusahaan, juga memperhatikan ukuran kinerja pada perspektif-perspektif yang lain yang sama pentingnya dengan perspektif keuangan.

Berdasarkan penilaian dari tiap-tiap perspektif Balance Scorecard diatas, maka:

1. Perusahaan dituntut untuk dapat mempertahankan kinerja pada perspektif keuangan dengan terus memaksimalkan laba perusahaan.

2. Dalam meningkatkkan kepuasan pelanggan, perusahaan perlu lebih detail untuk melihat ulang teknis pelayanan kepada konsumen untuk dilakukan perbaikan dan pengembangan.

3. Pada perspektif proses bisnis internal, perusahaan perlu lebih cepat lagi dalam pengembangan penjualan produk khusunya BBM jenis Pertamax. Hal ini berkaitan dengan peraturan pemerintah yang akan melarang kendaraan pribadi untuk mengisi bahan bakar kendaraannya dengan BBM Premium bersubsidi, karena BBM Premium bersubsidi hanya boleh digunakan untuk kalangan tertentu seperti masyarakat kurang mampu.

4. Pada perspektif pertumbuhan dan pembelajaran perusahaan perlu meningkatkan pelatihan dan pendidikan untuk meningkatkan produktivitas karyawannya.

\section{DAFTAR PUSTAKA}


Blocher, E. J., D. E. Stout dan G. Cokins. 2011. Cost Management: A Strategic Emphasis, $5^{\text {th }}$ ed. Jakarta: Salemba Empat.

Ciptani, M. K. 2000. Balance Scorecard Sebagai Pengukuran Kinerja Masa

Depan: Suatu Pengantar. Jurnal akuntansi dan keuangan, Vol.2, No.1, (Online:

$h$ ttp://puslit.petra.ac.id/journals/accou nting/, diakses tanggal 24 Oktober 2012).

Eko Sujianto, Agus. 2009. Aplikasi Statistik dengan SPSS 16.0. Jakarta: PT. Prestasi Pustakarya.

Gaspersz, V. 2005.Sistem Manajemen Kinerja Terintegasi Balance Scorecard dengan Six Sigma untuk Organisasi Bisnis dan Pemerintah. Jakarta: PT Gramedia Pustaka Utama.

Hansen, D. R., dan M. M. Mowen. 2009. Accounting Managerial, $8^{\text {th }}$ ed. Jakarta: Salemba Empat.

Harahap, S. S. 2011. Analisis Kritis atas Laporan Keuangan. Jakarta: PT Raja Grafindo Persada.

Hasan Iqbal, M. 2002. Pokok-Pokok Materi Statistik 2 (Statistik Inferensif). Jakarta: PT. Bumi Aksara.

Irawan, A.W. 2006. Persiapan Balance ScorecardSebagai Instrumen Pengukuran Kinerja Pada Pengelolaan Usaha Kecil (Studi Kasus: PP. Kecap Maja Menjengan, Majalengka). Skripsi Tidak Dipublikasikan, Studi Manajemen Agribisnis Institut Pertanian, Bogor. (Online

http://repository. ipb.ac.id/handle/123456789/50688, diakses tanggal 25 Oktober 2012).

Kaplan, R. Dan D, Norton. 1996. The Balance Scorecard Translating
Strategy Into Action. Edisi satu. United States of America: Harvard Business School Press.

Kotler, P. 2000. Marketing Management $10^{\text {th }}$ edition. Jakarta: PT Indeks.

Kurniati, S.S. 2009. Analisis Kinerja Pelayanan Jasa Pest Control Pada PT AGRION PUTRA CITRA OPTIMA Aplikasi Konsep Balance Scorecard. Skripsi Tidak Dipublikasikan, Ekstensi Manajemen Agribisnis Institut Pertanian, Bogor.

http://repository.

Ipb.ac.id/handle/123456789/23463, diakses tanggal 24 Oktober 2012).

Manahan , P.T. 2005. Manajamen Keuangan (Finance Management) Konseptual, Problem dan Studi Kasus.Jakarta: Ghalia Indonesia.

Martono dan D. A. Harjito. 2008. Manajemen Keuangan. Yogyakarta: EKONISIA.

Martono, N. 2011. Metode Penelitian Kuantitatif. Jakarta: RajaGrafindo Persada.

Mulyadi.2007. Sistem Terpadu Pengelolaan Kinerja Personel Berbasis Balance Scorecard.Yogyakarta: Sekolah Tinggi Ilmu Manajemen YKPN.

Nany, M., L. Raharjo dan K. W. Handini. 2008. Penerapan Balance Scorecard Sebagai Pengukur Kinerja Manjemen Pada Rumah Sakit Umum Daerah Indramayu (The Application of Balanced Scorecard as Performance Measurement at District Hospital of Indramayu). Jurnal Riset Akuntansi dan Keuangan Vol.4 No.1, hlm. 48-56.

Puspita, K. T. 2007. Perancangan Balance ScorecardSebagai Instrumen Pengukuran Kinerja Pada PT UNITEX, Tbk. Skripsi Tidak Dipublikasikan, Fakultas Ekonomi dan Manajemen Institut Pertanian Bogor. 
Putrayasa, M. A. 2011. Pengukuran Kinerja ditinjau Dari Empat Perspektif Balance Scorecard Pada Koperasi Mertha Yasa Di Desa Penarungan. Jurnal Bisnis dan Kewirausahaan. Vol.7 No.3,

http//p3m.pnb.ac.id/document/jurnal/133594 4667_Putrayasa.pdf, 15 Desember 2012)

Rangkuti, F. 2011. SWOT Balance Scorecard Teknik Menyusun Strategi Korporat yang Efektif plus Cara Mengelola Kinerja dan risiko. Jakarta: PT Gramedia Pustaka Utama.

Rivai, Veithzal dan Basri. 2005. Performance Appraisal: Sistem Yang Tepat Untuk Menilai Kinerja Karyawan Dan Meningkatkan Daya Saing Perusahaan. Rajagrafindo Persada. Jakarta.

Sipayung,F. 2009. Balance Scorecard: Pengukuran Kinerja Perusahaan dan Sistem Manajemen Strategis.
Jurnal Manajemen Bisnis, Vol.2, No.1, (Online, http//usupress.usu.ac.id/files/Jurnal Manajemen Bisnis Vol_2 No_1 Jan 2009, 24 Oktober 2012).

Sugiyono. 2011. Metode Penelitian Kuantitatif Kualitatif dan R\&D. Bandung: ALFABETA.

Sulistiyani, Ambar T. sidah.2003. Manajemen Suml a Manusia. Graha Ilmu: Yog.

Yuwono, S. E. Sukarno, M. Ichsan. 2004. Petunjuk Praktis Penyusunan Balance Scorecard Menuju Organisasi yang Berfokus Pada Strategi. Jakarta: PT Gramedia Pustaka Utama.

Zudia, M. 2010. Analisis Penilaian Kinerja Organisasi Dengan Menggunakan Konsep Balance Scorecard Pada PT Bank Jateng Semarang. Skripsi Tidak Dipublikasikan, Fakultas Ekonomi Dipenogoro, Semarang. (Online,

http//eprints. Undip.ac.id/23070, diakses tanggal, 24 Oktober 2012). 